\title{
O design no videografismo como ferramenta na construção de sentido
}

\author{
The design videographism as a tool in the construction of meaning
}

\author{
PEREIRA, Renato José Lopes; Especialista; \\ Faculdade Pitágoras de Londrina \\ rejolope@hotmail.com
}

GOMES, Rogério Zanetti; Doutorando;

Faculdade Pitágoras de Londrina

hola@rogerioghomes.com

\begin{abstract}
RESUMO
Este artigo tem como objetivo demonstrar o uso adequado das ferramentas do design na produção de vinhetas videográficas, como forma de enriquecer a construção de sentido, quando veiculado em rede nacional, em especial no uso de pictogramas, pela sua facilidade de leitura, proporcionando uma compreensão mais ampla dos signos utilizados.
\end{abstract}

Palavras-Chave: Design; Semiótica; Videografismo; Canal Futura.

\section{ABSTRACT}

This article aims to demonstrate the proper use of the tools of design to product video-graphic vignettes, to enrich the construction of meaning, when aired on national television, especially using pictograms, for easy reading, providing a broader understanding of the used signs.

Keywords: Design; Semiotics; Television Graphics; Futura Channel.

\section{Introdução}

O Canal Futura é um canal de televisão aberta, educativa, que nasceu no ano de 1998, como um projeto da Fundação Roberto Marinho, com o objetivo de ser um projeto social de comunicação, da iniciativa privada e de interesse público, utilizando uma linguagem plural para abordar temas de importância e interesse coletivo. Por ser um canal educativo, não pode veicular comerciais. Por isso, entre os seus conteúdos gerados para ocupar os intervalos estão as vinhetas feitas com elementos gráficos, ou como é chamado, "grafismo".

Essas vinhetas, que têm como objetivo informar e levar cultura para as pessoas, são realizadas por meio técnicas manuais, ou eletrônicas, mas sempre baseadas em princípios do design, além de ter sempre um objetivo de significar algo, por meio de seus signos.

A televisão é um dos meios de massa que ainda possui o maior alcance nos dias de hoje, e quanto mais sofisticadas ficam as produções, melhor técnica elas exigem. Por isso, se fará necessária uma compreensão dos termos "comunicação" e "design" e como estão conectados, além de suas funções uma para com a outra. Também se fará necessária a compreensão da influência que a cultura das mídias faz diante do momento em que a humanidade se encontra.

Por isto, este trabalho se propõe a realizar a análise de 1 vinhetas, para identificar os fundamentos do design utilizados, e a significação que eles carregam em si, por meio de seus signos e o estudo da "semiótica". 


\section{A Comunicação e o design}

Existem dois aspectos importantes que auxiliam no relacionamento entre os seres humanos. O que os faz comunicar (comunicação) e o que comunica por meio de sua forma e aparência (design).

A comunicação humana existe desde os primórdios da humanidade (FLUSSER, 2007), quando o ser humano ainda era um ser primitivo que pouco entendia o que o outro queria dizer. Mas, aos poucos foi incorporando sentido em gestos, sinais, ruídos e sons, de tal forma que criou um código, por meio do qual se comunicava com seus semelhantes. Para Flusser (2007, pág. 91), "a comunicação humana tece o véu do mundo codificado, o véu da arte, da ciência, da filosofia e da religião ao redor de nós". Logo, é por meio da comunicação que o ser humano compreende e codifica a realidade em que vive.

A primeira forma de comunicação de que o ser humano se utilizou foi a imagem, pois elas tem sido a forma de expressar dos seres humanos, desde as eras primitivas, milênios antes do surgimento da palavra. Outra forma de comunicação foi a escrita, que surgiu muito tempo antes de Cristo, mas só foi plenamente difundida pelo mundo após o século XV, depois da criação da prensa de Gutenberg (SANTAELLA, 1999).

A poesia está mais próxima da visualidade e da música que o da linguagem verbal. É na poesia que a ligação entre palavra e imagem (sons) chega a níveis surpreendentes. Percebemos que "a tal ponto a imagem está hoje introjetada na palavra poética que a mera menção do tema - palavra e imagem - parece conduzir o pensamento inexoravelmente à poesia" (SANTAELLA, 1999, pág. 71).

A palavra design é importada recentemente do inglês, e tem vários significados, como plano, desígnio, intenção, ou até a ideia de plano, desígnio, configuração (CARDOSO, 2004). Desta forma, o design trata das configurações das coisas e as intenções que elas comunicam ao ser humano, desde a sua idealização, planejamento, criação e compreensão que tem dos objetos criados.

Outro contexto que a palavra design ganha, segundo Flusser (2007, pág. 181), é de algo "conspirador malicioso que se dedica a engendrar armadilhas". Ele encontrou a origem da palavra grega mechos, que significa um mecanismo que busca a enganação, uma armadilha, como o Cavalo de Tróia (FLUSSER, 2007). Outra origem é o termo grego techné, que significa arte, relacionada ao carpinteiro, que, por meio da madeira bruta, cria e gera a obra que está entalhada dentro desta massa.

Desta forma, o design acabou por unir o mundo das técnicas e o mundo das artes, tomando esta forma que durante muitos anos foi negada, mas nos dias de hoje é entendida desta forma. Nesse contexto, Flusser (2007, pág. 184) afirma que "o design que está por trás de toda cultura consiste em, com astúcia, nos transformar de simples mamíferos condicionados pela natureza em artistas livres".

Com a popularização que as novas tecnologias injetaram no mundo do design, vieram também novos limites para a imaginação humana, pois o uso dessas ferramentas mecanizadas acaba por limitar o uso e produção de elementos que estão fora dos padrões dos programas. Surge assim a possibilidade de se limitar a criatividade, devido à limitação dos recursos do software. Mas não é o programa o responsável por isso; afinal de contas, nada é mais intrigante e misterioso que uma folha em branco, onde podem surgir inúmeras possibilidades de criação para a mente humana.

\section{Cultura das mídias}

Entre as mais variadas definições da palavra cultura, a que possui um sentido mais próximo das análises que serão realizadas neste trabalho é a utilizada pela semiótica, ou ciência dos signos. Para outras ciências, "a cultura é um meio para atingir um fim: a investigação do homem nas suas múltiplas realizações" (SANTAELLA, 1996, pág. 27). Na semiótica, a cultura é um dos elementos integrantes da linguagem, não um fim em si mesmo.

É na relação entre cultura e comunicação que se pode caracterizar o significado de cultura para a semiótica, identificando a função dos termos, já que os "fenômenos culturais só funcionam culturalmente porque são também fenômenos comunicativos" (SANTAELLA, 1996, pág. 29).

Existem muitos atributos que podem ser incluídos no termo cultura: cultura universal, cultura urbana, cultura dos séculos e cultura das mídias. Se cultura e comunicação são inseparáveis, nas mídias isso é ainda mais indistinguível, já que os meios são veículos de comunicação. Para estudar essa cultura, deve-se analisar as relações entre cultura e comunicação. 
Como a semiótica não separa cultura de mídia, se mostra como a área de investigação capacitada para estudar a produção cultural realizada pelos meios de comunicação. Para as áreas que separam os dois termos, fica inconcebível reconhecer as mídias como produtoras de cultura, sendo o termo cultura das mídias uma ofensa. Isso ocorre por que o conceito de cultura válido é aquele ligado às atividades dadas como nobres, como a literatura, o teatro, o cinema, as artes plásticas e a música, que normalmente são produzidas pelas elites culturais ou classe política dominante.

Sendo assim, cultura das mídias é "uma enorme e crescente diversidade de veículos de comunicação, tendo cada um deles uma função específica e diferencial" (SANTAELLA, 1996, pág. 30). Essas funções específicas de cada mídia produz efeitos diferenciais em cada público, de acordo com sua própria linguagem e diferenciais específicos. Para Santaella (1996), o crescimento constante das mídias, por si só, abalam as divisões estratificadas entre cultura erudita, popular e de massas. Perfazendo o efeito contrário, sua movimentação e interação ininterrupta dinamizam as relações das produções culturais dos diferentes tipos de mídia.

Para existir a comunicação, é necessário haver um transmissor, que transmite uma informação, e um receptor, que interprete e decodifique a mensagem. Logo, se não houver informação, não há comunicação. Assim como não há comunicação sem um meio de transmissão dessa informação, e eles precisam compartilhar de algum código para que um organize os códigos emitidos pelo outro. As mídias, desde a origem da imprensa escrita, se tornaram veículos oficiais de informação.

A diferença essencial entre comunicação e informação é que a primeira é um ato de informar intencionalmente. Como essa informação chega ao receptor é algo não ponderável e casual, já que não é possível controlar sua transmissão. A comunicação nas mídias funciona da mesma forma, transmitida sem pensar como a intencionalidade será recebida. Desta forma, a comunicação em massa tende a considerar seu público como uma massa homogênea, o que aumenta a margem do não controle da informação, falhando no gerenciamento da intencionalidade da comunicação, visto que na comunicação pessoal emissor e receptor vão ajustando os códigos e repertórios culturais dos signos, facilitando o entendimento de ambas as partes. Na comunicação em massa, não há dualidade comunicativa; logo, os signos que não pertencerem ao repertório do receptor ficarão incompreendidos.

Outro aspecto que atrapalha a informação não controlada nos meios é a propagação de signos e códigos, em vários sistemas sígnicos, misturando o verbal e o não-verbal. Logo, há uma confusão generalizada na interpretação da mensagem, que parece pobre no conteúdo, mas que reúne em si complexas redes semióticas.

A história dos meios de comunicação em massa começou com o livro impresso, a princípio utilizado para reimprimir escritos de manuscritos. Com o tempo, foram aparecendo os primeiros panfletos políticos e religiosos, no período medieval. Apenas duzentos anos depois a imprensa, do modo como conhecemos, surgiu, a partir de cartas com notícias que circulavam por meio de meios de serviços postais rudimentares. Os primeiros jornais tinham como características regularidade, ponto comercial fixo, vários assuntos, caráter público, sem identificar as fontes das informações, a não ser em jornais oficiais.

O jornal começou efetivamente a cultura das mídias, com suas características e particularidades que Ihe são próprias, Entre elas, a provisoriedade, que parece ser o principal motor da cultura das mídias, em antagonismo com a permanência das formas mais tradicionais de cultura. É a cultura do efêmero, do passageiro, $O$ jornal de hoje, no dia de amanhã já está ultrapassado; o filme que está em cartaz essa semana, na outra já não está; os programas de televisão, em especial o jornalismo, precisa de matérias novas e recentes, muitas vezes perdendo material, por questão de segundos na hora de produzir.

A mobilidade é outra característica importante na cultura das mídias, pois uma mesma informação passa repetidamente, em várias mídias diferentes, de acordo com suas características próprias. É essa capacidade de trânsito de informação de uma mídia a outra que faz com que o conteúdo dure pouco tempo e, enquanto dura, é multiplicado diversas vezes.

Existe ainda a proliferação das próprias mídias. Mídias da mesma natureza competem entre si, para conseguir maior audiência e mais anunciantes. R. Cirino (1974; apud SANTAELLA, 1996, pág. 28) defende a ideia de que "um dos princípios da liberdade democrática para o acesso a informação é que 
um grande número de pontos de vista diferentes possam coexistir no espaço-tempo", mostrando que mais pontos de vista diferentes de um mesmo fato ajudam o público receptor a entender melhor os fenômenos, e acolher o que mais lhe convém.

Essa proliferação não se dá somente entre mídias de mesma natureza, mas também de natureza diversa. Apesar de, à primeira vista, parecerem competir entre si, os meios acabam por criar redes intercomplementares, cada uma com seu potencial e limite que lhe é próprio, representando cada um uma função diferencial na rede das mídias. Uma notícia escutada pelo rádio poderá ser visualizada na televisão, e poderá despertar o interesse do público a ler a mesma notícia no jornal, que na revista será abordada de uma forma mais detalhada, Dependendo do acontecimento, posteriormente poderá ser publicada em um livro com quantidade de informações muito mais minuciosas. Esse contato entre redes fará com que as informações circulem e se complementem, refletindo na cultura geral, em que a cultura das mídias é o motor propulsor, que faz as diversas formas de cultura saltarem de setor para setor.

Assim, as mídias tendem a se engendrar como redes conectadas, em que cada mídia tem uma função específica. Por isso, quando uma nova mídia nasce, tende a redimensionar a função de todas as outras, provocando atritos e conflitos, até que todas se ajustem, de acordo com suas funções. Aconteceu com o impresso, no surgimento do rádio; depois com este, no nascimento da televisão; depois com o impresso, o rádio e a TV, no aparecimento da internet, mas todos esses meios continuam desempenhando sua função e interação, sem dar sinais de que vão acabar.

As mídias possuem uma pluralidade de dimensões e diversidade funcional internas, sendo a televisão a que melhor comprova isso, pois é uma mídia extremamente absorvente, que pode trazer dentro de si todos os outros tipos de mídia e cultura, como o cinema, o jornal, o teatro, a música, o esporte, discussões de política, entre outras possibilidades. É com essa força que a TV pode influenciar pensamentos, atitudes e comportamentos das pessoas. Mas, ainda assim, ela por si só não é forte o bastante para realizar mudanças sociais e culturais. O que ela realiza é uma potencialidade no impacto de certas mensagens e valores sociais que já estão latentes na sociedade.

Como a televisão tem um caráter antropofágico, em que ela absorve e devora as outras mídias e formas de cultura, acaba sendo a mais criticada, por acabar dando novas feições, de acordo com suas próprias características, como a perda dos emissores e receptores, limitando os sentidos, aos planos usados na TV, imagem pequena, perda de acústica, entre outros aspectos. Mas, no final das contas, ela absorve e impõe às outras mídias qualidades de organização, ritmo e aparência, de acordo com sua forma de ser.

As mensagens produzidas pelas mídias nos dias de hoje não são tão simples quanto parecem. Elas "se organizam no entrecruzamento e na inter-relação de diferentes códigos e processos sígnicos diversos, compondo estruturas de natureza altamente híbrida" (SANTAELLA, 1996, pág. 43). Dessa forma, do jornal à internet há conjugações simultâneas de diversas culturas e linguagens, misturando códigos e signos de estatutos semióticos diferentes entre si. Isso favorece a afirmação de que todas as mídias são por natureza intermídias e multimídias. Esse emaranhado de conteúdo e redes sígnicas acabam por afetar a compreensão do público afetado pela informação, causando uma margem de falta de controle no discernimento da mensagem.

Já as novas mídias, com seus fluxos contínuos e em grande quantidade de informação, possuem uma mobilidade e interatividade muito mais altas que as mídias tradicionais, causando uma seletividade maior por parte de quem recebe as informações. Elas se proliferam pelo reaproveitamento das mídias já existentes, causando uma grande transformação em suas produções e criações, em que muitas mídias tiveram até que se reinventar e se integrar dentro das novas mídias, como é o caso do rádio.

\section{A Televisão}

A televisão é um meio considerado como gerador de conteúdo banal, pelos críticos, que dizem que as coisas são muito diferentes fora da televisão. Essa banalização das mídias é resultado da industrialização da cultura e se estende a todas as produções intelectuais que a humanidade produz. Obras de arte de Da Vinci, Picasso e Monet, que possuem reproduções industrializadas à venda; a 
arte musical de Mozart, Beethoven, Bach; livros clássicos da literatura e demais produções culturais recentes possuem, em sua maioria, produtos de consumo, réplicas, cópias que qualquer pessoa, por menos culta que seja, pode levar para casa. Por isso é injusto acusar a televisão e culpá-la pela mercantilização do conteúdo cultural da humanidade. Mesmo a televisão, em todos os seus anos de existência, geriu para a humanidade grandes obras, para serem relembradas por toda a eternidade. 0 que dizer dos trabalhos realizados por David Lynch, Andy Warhol, Jem Cohen, Guel Arraes, Federico Felini? Eles e tantos outros ajudaram a criar uma ética e uma estética para a televisão.

Existem dois caminhos para se abordar a televisão. Um a leva em conta como fenômeno das massas, realizando uma análise sociológica, para verificar sua influência. Outro a analisa "como um dispositivo audiovisual através do qual uma civilização pode exprimir a seus contemporâneos os seus próprios anseios e dúvidas, crenças e descrenças..." (MACHADO, 2000, pág. 11). Neste, a questão da qualidade é um ponto fundamental de análise.

Entre as várias teorias sobre o que é a televisão, para este trabalho será tomada como base a de Arlindo Machado (2000, pág. 12), de que "a televisão é e será aquilo que fizermos dela". Para isso o autor afirma que os meios de comunicação não estão predestinados a serem fixos e que é a partir da interpretação da sociedade, ao apoiar conteúdos e rejeitar outros, que será construído um conceito e prática do que é televisão. Ou seja, o que ela é ou deixa de ser está intrínseco na vida dos agentes que estão em relação com ela, sejam os produtores, consumidores, críticos ou outros mais.

Os estudiosos de televisão têm usado o termo "televisão de qualidade", para designar o tipo de televisão ideal para se assistir. Mas o uso desse termo é um pouco confuso, pois não se usa o adjetivo qualidade para outras artes, como música, teatro, cinema. Apenas são o que são, pelas suas características, da mesma forma que a televisão. Outro equívoco a que o termo pode levar é a subjetividade do que é de qualidade para um determinado público. Para alguns, será o conteúdo exclusivamente educativo e/ou cultural; enquanto para pessoas de mentalidade mais conservadora, serão apenas programas que não mostrem violência, palavrões, cenas de sensualidade. De qualquer forma, o conceito qualidade ainda deve servir como referencial, sabendo distingui-lo no uso correto da palavra, e sem explicar de forma ingênua ou apressada.

Essa visão da televisão, vinda dos donos das mídias, e estranhamente seguida por teóricos da comunicação, de que a televisão era um meio popularesco, de massa, fez com que algumas experiências ricas, poderosas e estimulantes, passassem despercebidas. Nos seus 50 anos de história, a televisão conseguiu criar um repertório de obras muito maior e com conteúdo denso e amplo, com a capacidade de incluí-la entre os fenômenos culturais mais importantes de nosso tempo.

Apesar de muito difundida e consumida, a televisão ainda é o mais desconhecido sistema de expressão da atualidade. Percebe-se isso nos estudos sobre ela, em que se fala pouco sobre os programas que a compõem. As que examinam alguma experiência tratam de banalidades óbvias, como os sitcoms americanos, as novelas mexicanas, e a cobertura de fatos políticos do telejornalismo. Isso mostra uma visão da televisão como "serviço", em que o que importa é o que acontece fora da tela, na política, economia, que forjam as produções e as condições de recepção. Por isso pouco se presta atenção nos trabalhos audiovisuais produzidos e ao que os telespectadores realmente assistem, Ao invés disso, olha-se mais "para a estrutura genérica do meio, entendida como tecnologia de difusão, empreendimento mercadológico, sistema de controle político-social, sustentáculo do regime econômico, máquina de moldar o imaginário..." (MACHADO, 2000, pág. 16). Essas abordagens são válidas, mas deixam de lado o mais importante: a análise daquilo que nesses mais de 50 anos de produção tiveram relevância e marcaram época, destacando-se da imensa massa audiovisual dentro da cultura do nosso tempo.

Não é uma tarefa fácil analisar a televisão de uma perspectiva valorativa, fugindo do conceito de uma massa homogênea. Para isso, Machado aponta duas principais maneiras de tratar a tv, de acordo com o modelo de Adorno e o de McLuhan. Adorno cita em seus estudos que conseguiu colher algumas amostras de televisão, e analisando que no tempo de suas pesquisas não havia videotape, chega-se a conclusão de que ele analisou apenas textos, como roteiros e argumentos dos programas. Assim, ele analisa não a partir de uma observação sistemática do que a televisão exibe, mas realiza uma amostragem tendenciosa, que claramente quer provar que a televisão era um "mau" objeto. 
Ou seja, ele ataca um objeto sem realizar uma pesquisa sobre o que a televisão estava realmente exibindo naquela época, como o programa do pianista Glenn Gould, que apresentava musicais pela Canadian Broadcasting Corporation, de Montreal, com quarenta programas dedicados à análise musical, abordando a música nova, e com referências a Adorno. O que comprova o quanto superficial foi a pesquisa de Adorno.

Mcluhan comete um erro semelhante, mas ao contrário, se para Adorno a televisão é totalmente má, independentemente do que ela veicule, para McLuhan, a televisão é naturalmente boa, nas mesmas condições. Ele, ao contrário de Adorno, conhece seus objetos de análise, mas os dois tratam a televisão "como uma estrutura abstrata, modelo genérico de produção e recepção, sem consequências significativas no nível dos programas" (MACHADO, 2000, pág. 19).

O grupo adorniano tem a televisão como má por natureza, mesmo que nela fossem exibidos trabalhos em telas enormes de alta qualidade; e para os macluhianos ela seria boa, mesmo que só passasse programas de péssimo conteúdo. 0 motivo de ataque e defesa de ambos os grupos é o mesmo: sua estrutura tecnológica e mercadológica, ou seu modelo abstrato genérico. Para os dois, a televisão não é lugar para produtos que mereçam singularidade.

Mas é preciso ir além. A televisão deve ser pensada como um conjunto de todos os trabalhos audiovisuais, variados, desiguais e contraditórios que a constituem. Os aspectos tecnológicos contam muito, principalmente nos dias das televisões de alta definição, em 3D e portáteis, mas devem ser levadas em consideração as mensagens compostas por imagens e sons, que é o que mobiliza os produtores e telespectadores.

Televisão é um termo amplo, que pode ser usado desde as produções regionais de um pequeno canal de tv comunitária, ou a cabo; conteúdos feitos por produtores independentes, como o que é produzido pelas grandes redes privadas mundiais. Por isso é necessário esclarecer qual sentido será utilizado para esta análise.

Uma verdadeira crítica à televisão busca estabelecer critérios rigorosos que separem o que é bom daquilo que é ruim, que elevem os níveis de exigência do público, e premiar com estudos e comentários críticos aqueles que se esforçaram por passar por cima de obstáculos e modelos ultrapassados, tornando a televisão um lugar de arte e conteúdo.

Ao redor do mundo surgem muitas iniciativas que valorizam a cultura na televisão, mostrando que ela não é o que sociólogos, tecnólogos e estrategistas do marketing tentam fazer dela. Ela deixou de ser o purgatório das mídias de massa. Exemplos disso no Brasil, são os programas do Canal Futura, como Passagem Para..., Mundo.Doc, entre outros. Até mesmo as grande redes, como a Rede Globo de Televisão, têm tido seus momentos de arte, como com a novela "Cordel Encantado".

Nos anos 80 foi usado pela primeira vez o termo televisão de qualidade, na Inglaterra, e passou a ser uma expressão usada como referência para abordar a televisão de uma forma diferenciada, por críticos e estudiosos, mas que não havia uma definição clara do termo.

Ainda nos dias de hoje está longe de ser um consenso sobre o que é televisão de qualidade para os intelectuais mais tradicionais, que não conseguem enxergar a estética de produtos produzidos em massa. Para eles somente tem valor aquilo que tem tradição cultural, que não pode ter nada em comum com a descartável e superficial produção de produtos em série dos dias de hoje. Falar de qualidade e criatividade na produção televisiva é perda de tempo. A única função da televisão é a introdução dentro do campo da cultura secular e legítima, ao público leigo. Ainda dentro desse contexto, apenas a difusão das culturas mais antigas e reconhecidas para a população pela televisão seria um verdadeiro valor para este meio.

Existem aqueles que defendem a ideia de que a demanda comercial e a industrialização do conteúdo não elimina a criação artística a não ser que se considere como arte apenas o artesanato e coisa feitas manualmente. Na verdade, o que se percebe é que a arte é criada a partir do contexto social de cada época, de suas demandas e recursos, vindo do interior dos modelos econômicos vigentes. Muitas dessas artes foram produzidas dentro de ambientes hostis, controlados por falta de recursos, valores religiosos, que na dificuldade conseguiam se recriar e inovar.

O termo televisão de qualidade apresenta também problemas, por ser utilizado com muitas intenções diferentes. Para Geoff Mulgan (apud MACHADO, 2000, pág. 24), existem ao menos sete 
significados diferentes para a palavra qualidade, quando se discute televisão: (1) conceito técnico de usar bem os recursos expressivos do meio (fotografia, roteiro, atuação, etc), muito utilizado por profissionais da televisão; (2) a capacidade de detectar e transformar em produto as demandas da audiência ou da sociedade, uma abordagem utilizada por comunicólogos e profissionais de marketing; (3) uma competência para explorar recursos da linguagem de forma inovadora; (4) a abordagem ecológica, que prefere privilegiar os aspectos morais, pedagógicos, e edificantes que a televisão pode ter; (5) analisando a televisão como ritual coletivo, sua qualidade pode ser o seu poder de mobilização nacional em torno de assuntos de interesse coletivo; (6) há ainda os que encontrem qualidade nos programas que valorizem diferenças, individualidades, os excluídos, em vez de integração nacional e incentivo ao consumo; (7) diante da dificuldade de conciliar os diversos interesses, sua qualidade pode estar na diversidade, considerando como a melhor televisão a que oferecesse um leque mais amplo de experiências.

O conceito ambíguo de televisão nos leva a buscar uma definição elástica e complexa que valorize devidamente os trabalhos em que os interesses comerciais não sejam muito conflitantes com a inovação e a criação; que a liberdade de expressão não seja avessa à demanda da audiência; que as necessidades de diversidade e segmentação não estejam muito fora das grandes questões nacionais e universais.

Numa realidade em que não se chega a um consenso sobre a natureza da mídia, seu papel na sociedade e o modo que deve ser produzida e recebida, a "televisão de qualidade" deve oferecer uma grande variedade de valores e propostas que unam os vários tipos de qualidade. Essa discussão sobre a qualidade da televisão deve ser contínua, pois é por meio da crítica que se pode verificar o que é qualidade, e o que não é, sendo essa discussão, um dos processos de se fazer a tv.

Entre os recursos e produções televisivas, o grafismo televisivo, ou vídeo grafismo, é muito utilizado em comerciais ou vinhetas nos programas de TV, ou mesmo durante os intervalos (brakes). Esse será o assunto a ser tratado detalhadamente a seguir.

\section{O grafismo televisual}

A rica composição das vinhetas de apresentação de programas, ou os materiais de identidade de um canal, faz, nos dias de hoje, do grafismo televisual uma das formas artísticas mais ricas. Seu conteúdo colorido, seu ritmo e velocidade leva aos lares dos telespectadores o que há de mais avançado em galerias de arte e, o melhor de tudo, ela chega até o espectador em sua própria residência, não necessitando ir até galerias de artes, nos grandes centros.

Tudo começou com a apresentação de créditos nos anos 50, de filmes norte americanos que, na busca pela inovação e novas formas de apresentar os caracteres, acabou criando uma nova forma de arte. $\mathrm{O}$ impacto de alguns créditos eram tão grandes que acabaram se tornando maiores que os próprios filmes. O nome mais importante dessa época, foi Saul Bass, de Chicago, discípulo de Gyorgy Kepes, na New Bauhaus. Entre as suas obras estão as aberturas de "Psicose", "Um Corpo que Cai" e "Anatomia de um crime". Também são lembrados os nomes de James Pollac, Maurice Binder e Robert Freeman, este último por suas produções cinematográficas com o grupo de rock inglês, The Beatles.

As aberturas que eles produziram combinavam de forma harmoniosa cenas filmadas, animação, tipografia e gráficos e criavam uma nova forma de comunicar que não se conhecia no cinema da época. Suas criações possuíam um cunho extremamente industrial, que era o da produção cinematográfica de Hollywood e, ainda assim, eram artisticamente inovadoras e criativas. Nas suas criações audiovisuais era possível integrar todos os meios e todos os sentidos. Bass foi o artista que conseguiu melhores resultados na combinação de som e imagem, sempre com o apoio de sua esposa, Makatura Bass, que era compositora.

Essas inovações gráficas não foram muito assimiladas dentro do cinema, por sua vocação realista. Essa linguagem moderna dura na maioria das produções, por no máximo quatro minutos, para depois seguir com sua concepção linguística monótona e seus modelos criados no século XIX. Em alguns casos, artistas como Saul Bass são contratados para utilizar sua criação, mesmo dentro dos filmes, como no caso do filme Psicose, em que ele realizou uma concepção artística mais moderna, 
mostrando o potencial do cinema, já no século passado.

O videografismo se desenvolveu mesmo na televisão, devido à sua natureza eletrônica e sua abertura a tendências avançadas, auxiliando no sintetismo do grafismo eletrônico, feito por computador. Desse casamento da televisão com a computer art, nasceu o grafismo televisual, ou television graphics, que são todos os recursos visuais, normalmente tridimensionais e dinâmicos, utilizados na identificação visual da rede, de algum programa, ou produto anunciado, assim como também o são os créditos, chamadas e toda e qualquer produção com elementos visuais que se sobrepõem às imagens filmadas por câmeras. Assim, o grafismo saiu da abertura e agora faz parte de toda a programação, surgindo voando por chamadas, propagandas e vinhetas, geralmente sincronizados com a música, levando ao telespectador um mundo animado e colorido.

A partir de 1962, com o surgimento da computação gráfica, por meio de um sistema de desenho interativo por computador, desenvolvido por Ivan Sutherland, abriu-se um leque enorme de possibilidades para a imagem eletrônica. Enquanto o cinema utilizou o computador para simular realidades, a televisão acabou por se apossar e tornar o grafismo uma de suas características.

Por gráfico televisivo, entendem-se vários recursos em que são utilizados títulos, créditos, textos e gráficos usados nos programas, no material promocional da rede, e os spots de identidade veiculados para mostrar a marca do canal. Esses materiais sempre buscam colocar a logo do canal de forma dinâmica, que muitas vezes se modifica ao longo de um intervalo de tempo. A logomarca, que em sua origem era estática, na televisão passa a ser movimentada e tridimensional.

A exibição da logo, além de sua função simbólica, também serve como pontuação da programação, separando as unidades de transmissão, geralmente exibidas antes ou depois de um programa. Possui um sinal imperceptível para o espectador, mas detectável pelos equipamentos de transmissão que servem para orientar as retransmissoras quando entrar na transmissão da rede ou para o momento em que vão transmitir de forma independente.

Até o início da década de 60, os gráficos eram telas desenhadas a mão por um artista gráfico com imagens e textos referentes ao programa e seus patrocinadores, filmados por uma câmera. Algumas vezes eram utilizadas técnicas de animação cinematográfica, sendo a CBS a primeira a animar utilizando essas técnicas, além de ser a primeira a unificar as fontes usadas nos textos da grade, além de ser a primeira a utilizar a logo como identidade visual do canal.

De 75 a 81 viu-se a era de ouro da introdução do grafismo digital na TV, normalmente produzido por caros computadores de grande porte, quando se desenvolveram os algoritmos de processamento, modelação, iluminação, animação e texturas. A partir de 81, as logos produzidas por artistas plásticos e gráficos encomendados pela MTV (Music Television) fizeram com que ela fosse a rede que mais assumiu a proposta da construção gráfica no audiovisual. Sua opção foi pelo diferencial, por construções mais sujas e underground, fora dos padrões geométricos e limpos que reinava nas outras redes. Assim, sua logo em permanente mutação, sem consistência aparente, com fisionomia mutante, foi facilmente reconhecível, graças a sua estética indomesticável e seu toque de surrealismo. Por isso o conteúdo da própria emissora e dos comerciais veiculados acabaram por adquirir esse espírito gráfico e as inovações visuais.

A Rede Globo de Televisão foi no Brasil a empresa que mais investiu e trabalhou com o grafismo, sendo uma das pioneiras, inclusive mundialmente, no uso de modelação e animação por computador em suas vinhetas, com suas enormes equipes de designers, ilustradores e técnicos. Seus trabalhos são marcados pela sofisticação, desde logotipos animados, aberturas de novelas e telejornais, como as aberturas do Fantástico, Jornal Nacional e das novelas Corpo a Corpo e Sinal de Alerta.

A função e o uso dos graphics tem ainda visões diferenciadas. Os adversários da televisão falam que não têm utilidade, a não ser o mero efeito pirotécnico. Outros reconhecem o papel estrutural e buscam compreender seu papel estrutural, como:

Seus motivos, figuras e tropos, como a indução de velocidade, a sugestão de monumentalidade, o efeito de imersão, ou ainda a simulação de um mundo sem gravidade, cuidando para ver como tudo isso funciona de prestígio e credibilidade, ou como estratégia comercial para vender produtos (MORSE, apud MACHADO, 
2000, pág. 203).

Isso tudo não é nada diferente de como as artes eram tratadas nos períodos renascentista, romântico, ou realista, que serviam de interesse para as classes políticas dominantes econômica e politicamente. E isso não quer dizer que paralisa ou debilita a força criativa e o potencial criador daqueles que têm algo a acrescentar no seu tempo. Nos dias de hoje nada tem contribuído mais para a renovação do gosto e sensibilidade para as artes visuais da população que o grafismo televisivo. Foi por meio dele que toda uma geração aprendeu a lidar com problemas de distribuição e otimização de informação na televisão, além de resgatar o prazer de ler, ver e ouvir num novo veículo de comunicação, como a internet nos dias de hoje.

\section{Os pictogramas e a representação sígnica}

Os pictogramas são a origem de todas as escritas, criadas de forma natural pelos seres humanos. O estudo da evolução da linguagem em suas diferentes formas, levam segundo Frutiger (1999), a duas principais categorias: as escritas que permaneceram figurativas e as escritas alfabéticas.

A origem das escritas pictóricas remontam ao quarto milênio antes de Cristo, na região da Mesopotâmia, com os povos sumérios. As primeiras escritas eram grafadas em argila, feitas provavelmente com uma espátula. Essas escritas se limitavam ao essencial, em que os sinais se uniam a outros, para criar significados mais complexos, como no caso do símbolo para jardim que unia os símbolos de contorno e grãos.

Enquanto os egípcios utilizam figuras estáticas, os sumérios preferiam o movimento, criando suas mensagens dinâmicas, sobre placas de barro queimadas, e possuíam uma forma mais alongada e triangular, chamada escrita cuneiforme.

Essas escritas foram se transformando e se simplificando para se adaptar às línguas de povos vizinhos, deixando de lado o emprego pictórico para o uso fonético dos sinais, reduzindo também o número de figuras. Sendo essa escrita completamente difundida, como o meio de "transportar o pensamento". Posteriormente a escrita cuneiforme foi substituída pela aramaica que continha 22 sinais, em contraposição com os quase mil sinais da outra.

Além desses modelos de escrita, várias outras civilizações antigas desenvolveram pictogramas com o intuito de desenhar seus pensamentos, demonstrar por meio de sinais gráficos suas ideias, pensamentos e até mesmo cultura. Entre as mais conhecidas pelos estudiosos estão os hieróglifos egípcios; as escritas da ilha de Creta; as escritas pictóricas na Síria, no Vale do Indo, na Índia, da Ilha de Páscoa, a escrita rúnica, do norte da Europa; a escrita circular chinesa; e as escritas pictóricas dos maias e astecas.

Desta forma, percebe-se que o pictograma é forma mais antiga de registro de conhecimento do ser humano que com a difusão do alfabeto, acabou ficando um pouco esquecida. Com a dificuldade de expressas algumas coisas apenas com o alfabeto, principalmente no campo da ciência e da indústria, existe uma demanda cada vez exigente na produção de novas convenções pictagóricas e liguagens de sinais. Em especial na publicidade, na criação de marcas e logotipos, em que muitos apresentam semelhanças entre si,o que mostra a perda do conhecimento antigo da cultura de sinais, ou uma orientação unilateral dos desenhistas.

Com o crescimento das grandes cidades e o aumento no fluxo de veículos, o senso natural de direção não basta para se localizar ou encontrar uma direção. Além do surgimento de novos caminhos e meios de transporte o que requer uma sinalização de símbolos claros e que não transmitam instruções equívocas.

Com os recursos técnicos e a difusão instantânea de informação pelo mundo, gerou no público receptor uma maior facilidade a compreender mensagens transmitidas por imagens, do que informações faladas. Essas imagens, mesmo que impressas são mais eficazes ao comunicar o seu sentido, em um relance, o que não acontece com a verbal que necessita de mais tempo e necessita da criação de uma figura para si, como acontece com o leitor ou o ouvinte.

Atualmente se percebe um interesse maior pela compreensão de sinais com conteúdo simbólico em vários campos, fazendo em alguns casos com que a letra alfabética perca seu "poder de 
atração como sinal, tornando-a um objeto funcional necessário e quase banal" (FRUTIGER, 1999, pág. 193). Por isso, a função das imagens pictagóricas num mundo complexo, é sinalizar, em locais onde a linguagem seria excessiva.

Ainda segundo Frutiger (1999, pág. 318), os pictogramas são cada vez mais usados nos sinais direcionais e informativos por duas razões: a limitação necessária das placas e a própria linguagem. Ele afirma que "as redes de estradas e ferrovias, além das linhas aéreas e de navegação, ultrapassam quaisquer fronteiras territoriais, linguísticas e étnicas". Se fossem feitos letreiros em várias línguas as dimensões seriam muito grandes e de difícil leitura.

Os sinais pictóricos foram mais utilizados nas últimas décadas para informar, o que causou uma mudança no modo como as pessoas lêem. Alguns itinerários não são possíveis de se fazer sem utilizar alguns pictogramas, que são classificados em três tipos diferentes. O primeiro é o tipo de pictograma que abrange os sinais como imagens reais, em forma de silhueta e não deixa dúvidas de sua mensagem, independente da língua. Exemplos conhecidos, são os pictogramas da silhueta de telefone, ou um cigarro cortado com um traço diagonal.

Já o segundo tipo precisa de esforço mental e não é compreensível à primeira vista, pelo uso de diagramas, como os sinais de trânsito que indicam mão dupla, preferencial, entre outros. Nesse grupo de pictogramas são inventados novos sinais de significados diferentes constantemente, não deixando claro seu sentido verdadeiro, necessitando de algum aprendizado anterior para uma real compreensão.

Os pictogramas que não derivam de diagramas, nem de figuras, mas de sinais abstratos são o terceiro grupo, que necessitam de aprendizado para compreendê-los. Depois de compreendidos a informação é transmitida espontaneamente. Exemplos desse tipo são os sinais de proibido, ou as cores do semáforo, que fazem parte das informações assimiladas.

Os pictogramas representam sempre a expressão de uma época, e em todos os lugares permeia e marca, sendo capazes de indicar o futuro, a partir da conservação do passado.

\section{Canal Futura}

O Canal Futura é um projeto de comunicação de iniciativa privada, criada há 13 anos pela Fundação Roberto Marinho, ligada diretamente à Rede Globo, maior canal de televisão do Brasil. Ela atua em várias regiões do país, por meio de parcerias com empresas e Universidades e tem como objetivo atrair e educar por meio de seus programas.

Segundo sua página oficial, o Futura tem como missão "contribuir para a formação educacional da população, desenvolvendo as capacidades básicas da criança, do jovem, do trabalhador e de toda a sua família". Seus trabalhos e produções seguem alguns princípios e valores essenciais, que são o espírito comunitário, o pluralismo cultural, o espírito empreendedor e a ética.

O canal procura transmitir seus princípios e valores vinte e quatro horas por dia, para alcançar crianças, famílias, jovens e trabalhadores, utilizando uma linguagem plural que aborde temas de interesse coletivo. Por isso entre suas pautas estão "a saúde, o trabalho, a juventude, a educação, o meio ambiente e a cidadania" (CANAL FUTURA, 2006). Ele busca ser um aliado da sociedade em busca de um mundo melhor.

O público do Futura interage com a programação, trabalhando os conteúdos no seu cotidiano, ampliando o conhecimento e o diálogo entre diversos grupos sociais, articulando novas redes e conexões, falando de si mesmo e com os outros. A criação dessa nova linguagem televisiva é realizada por meio da participação de novas gerações, em que se manifesta a pluralidade social.

O canal se mantém com parcerias entre organizações da iniciativa privada, unidas pelo compromisso social de investir em ações que promovam impacto em áreas prioritárias da agenda nacional. São mantenedores do Futura: Bayer Schering Pharma; Fundação Bradesco; CNI; CNN; FIESP; FIRJAN; Fundação Itaú Social; Fundação Vale; Gerdau; SEBRAE; TV Globo; Votorantim.

Segundo pesquisa do Instituto Datafolha do ano de 2009, 68.2 milhões de brasileiros têm acesso ao canal, 36 milhões de brasileiros assistem ao canal regularmente, e já foram exibidos 83 mil horas de programação, com cerca de 13 mil programas exibidos. O Futura mantém parceria 
com 13.304 instituições. Foram capacitados mais de 425 mil educadores por meio dos cursos do canal. Dois milhões de pessoas, em média, usam a programação nas suas respectivas instituições.

O canal é transmitido em todo o país, e pode ser sintonizado na parabólica, na polarização vertical 20, em todo o país, em TV aberta em UHF e VHF em várias localidades do país, sendo transmitida também por cabo e miniparabólicas (SKY, canal 8).

Entre os telespectadores que acompanham o canal pela parabólica, cerca de $70 \%$ classe pertencem às classes C, D e E (público acima de 16 anos), e 73\% das classes C, D e E (público de 4 a 12 anos). Existem ainda, em todo o país, cerca de 30 emissoras ligadas a universidades, que retransmitem o sinal do Futura, aliado à programação local. Os telespectadores do canal apresentam um engajamento social bem maior do que os que não acompanham o Futura. Segundo pesquisa realizada pelo Instituto Datafolha, em dezembro de 2005, $78 \%$ dos que se declararam telespectadores do Futura afirmaram que, ao assistir um programa, pensam e refletem sobre o assunto. Cerca de $72 \%$ disseram que vão aplicar na vida o que ouviu; $70 \%$ indicariam o canal para os jovens e $65 \%$ buscou mais informações sobre o tema que assistiu.

Em outra pesquisa, realizada no ano de 2006 , os que se declararam telespectadores do Futura se mostraram: mais propensos a definir a sua raça através da identidade cultural e menos propensos a usar a cor da pele como critério relevante; interessados em abrir seu próprio negócio; mais propensos a respeitar diferenças (gênero, regionalismos, referências culturais e estéticas) e menos propensos a preconceitos e racismo; dispostos a conversar mais sobre o que veem no TV no seu dia a dia.

O Canal Futura vive de parcerias com empresas, fundações, instituições financeiras, associações de classe e grupos de comunicação que apoiam o canal, investindo em educação e ações que atendam à sociedade. $\mathrm{O}$ modelo de parceria é pioneiro, com organizações de iniciativa privada líderes em seus segmentos, que têm consciência da importância de participar de forma ativa na realidade social, somando esforços para levar educação de qualidade a mais pessoas, por todo o país.

\section{Análise de vinheta}

Após serem considerados vários aspectos relacionados à produção audiovisual, a televisão e o videografismo a seguir serão realizadas análises dos fundamentos do design e análise semiótica da vinheta que tem o título de "Que a Esperança Seja Uma Escolha" (CANAL FUTURA, 2011), produzida pelo Canal Futura, em abril de 2011.

A vinheta foi produzida, após o acontecimento que chocou todo o país, uma chacina que aconteceu no Realengo, Zona Oeste do Rio de Janeiro. No dia 07 de abril de 2011, um ex-aluno assassinou 11 crianças a tiros após invadir uma sala de aula da Escola Municipal Tasso da Silveira. A vinheta foi criada com o intuito de levar esperança à sociedade, diante do triste acontecimento da época. Segundo o coordenador do setor de videografismo do Canal Futura, Stânio Soares, em uma conversa telefônica, foi um projeto produzido rapidamente, a partir da locução com a mensagem de esperança, pois foi uma produção relacionada com o factual, e havia a urgência na veiculação. Por isso eles optaram pelo trabalho com pictogramas, para comunicar de maneira mais fácil a mensagem produzindo a associação.

\section{Análise dos Fundamentos do Design}

Os fundamentos do design servem para entender a estrutura e a forma como uma peça de design foi criada. São parâmetros universais reconhecidos na maioria das produções gráficas, fotográficas, videográficas entre outras formas de expressar a arte por meio do design. Para esta análise será utilizado como referência o livro Novos Fundamentos do Design (LUPTON e PHILLIPS, 2008). Sendo assim, a análise será feita seguindo os seguintes fundamentos: simetria/assimetria, repetição, ritmo, escala, textura, cor, figura/cor, hierarquia, modularidade e movimento.

Verificam-se os princípios de simetria, assimetria e também repetição, nos quadros onde se encontram os pictogramas de seres humanos, gerando um contraste por conta das diferenças de 
tamanho dos elementos. Também se utiliza da repetição, quando se fala de paixão e necessidade, e se repetem os pictogramas que representam a paixão e a necessidade, com o intuito de reafirmar o argumento. E a representação da casa, que aparece quando se cita a família, quando se explica a chacina e no final, quando a cena se torna colorida e se fala de esperança. O ritmo das imagens segue lentamente, mas, se for analisar quadro a quadro, eles são estáticos, pois seus elementos não possuem formas que representem a ação.

Também o conceito de escala é muito utilizado, para representar o país e seus vários habitantes, com os elementos humanos de várias proporções espalhados pelo mapa. Ao demonstrar a família também é utilizada a escala, para representar os pais (maiores) e o filho (com proporção menor).

Em relação à textura, no vídeo percebe-se a presença e ausência em seus elementos. O plano de fundo, que é a simulação de uma parede, em tom cinza azulado, possui uma textura específica, mas os elementos que perpassam sobre ela, acabam por não possuir textura, ou quando possui, ela é apropriada do fundo pela transparência, como na cena em que o verde se sobrepõe ao fundo e acaba se apossando da textura da parede.

Quando se trata de cor, o vídeo a princípio tem o plano de fundo com tons pálidos, numa cor terciária e os pictogramas, em branco, ou preto, para poder ter um contraste entre os elementos, e no final, ele assume tons vivos de verde, com alguns raios solares, em amarelo, que é uma cor primária. Até a casa pálida ganha um pouco de cor, num branco mais vivo e um telhado laranja. E na assinatura o tom do verde vivo, da logo do Canal Futura contrasta com o fundo neutro do início do vídeo.

A interação entre figuras/fundo é harmônica, visto que em praticamente o fundo é o mesmo, neutro, e os elementos vão se sobrepondo sobre ele. Apenas quando a televisão passa com sua tela transparente, que ela se apossa do fundo, criando uma sobreposição, e quando o fundo assume tons verde vivo, que sofre um pouco de alteração em relação a interação pois, ali se torna parte ativa da imagem.

A hierarquia é utilizada para chamar a atenção às imagens que ficam centralizadas, no meio da tela, com pequenos textos abaixo, que muitas vezes acabam por passar despercebidos, principalmente pelo apelo forte que os pictogramas possuem e o fascínio que a imagem exerce no olho humano.

Os símbolos utilizados, são o destaque do vídeo, pois é a partir deles que a mensagem é passada ao espectador. Para Lupton (2008, pág. 168), "símbolos são geralmente baseados em módulos geométricos que se reúnem para criar uma miríade de formas e funções". Verifica-se assim, que o fundamento modularidade está presente no vídeo, pelos pictogramas, como vemos abaixo nas figuras (Fig. 04, 05, 06 e 07):
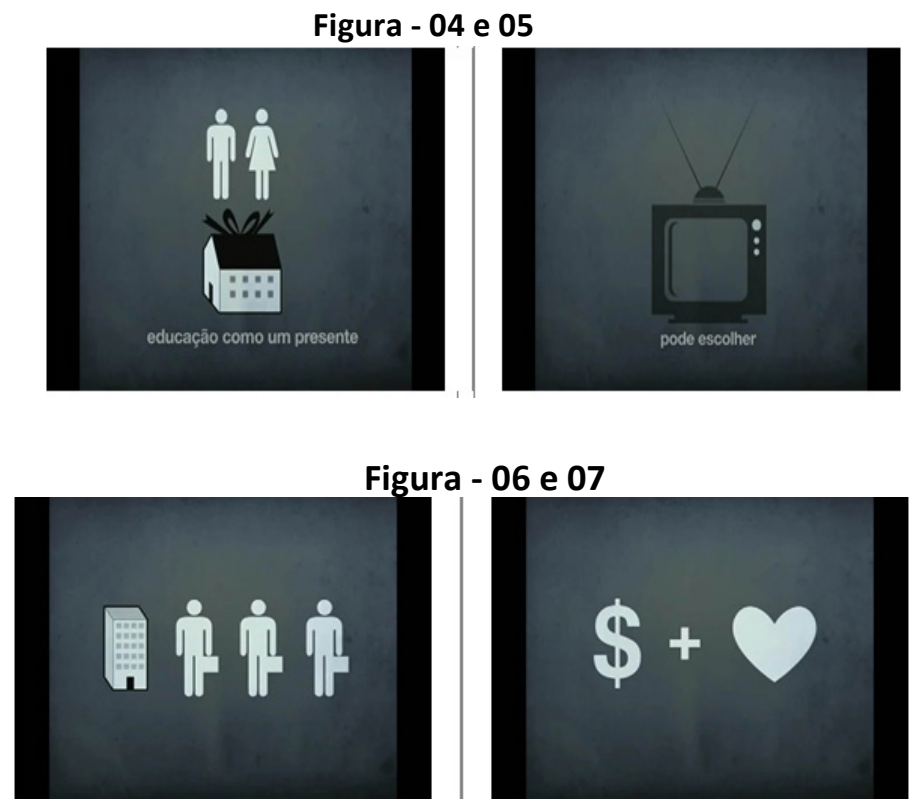

O movimento utilizado é simulado, pois as figuras em si, não possuem movimento, visto que são 
símbolos estáticos. Essa animação digital dá vida ao vídeo que se torna vivo. O designer criou apenas os quadros chaves, e deixou com que o software criasse os quadros intermediários, num processo que é conhecido como tweening. É um processo mais rápido e prático, mas acaba por ter pequenos problemas, como sombras indesejáveis e contornos sujos. Assim, cada quadro animado acaba por criar a história e passa a mensagem ao telespectador por seus elementos. E nas tela final, quando a logo entra, existe um movimento de linhas circulares que saem da logo, como nas figuras abaixo (Fig, 08 e 09):

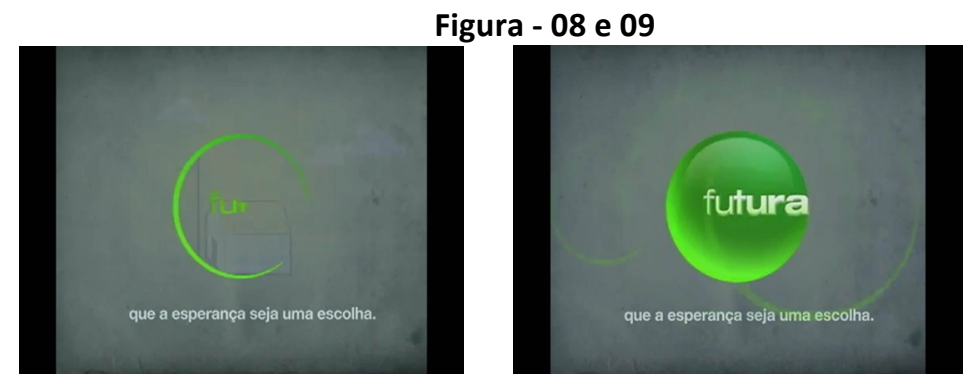

\section{Análise Semiótica}

A análise semiótica será realizada, de acordo com o percurso para aplicação apresentado por Santaella (2005), no capítulo 2 de seu livro, "Semiótica Aplicada".

Segundo a classificação feita por Santaella e Noth (1999, apud: Santaella, 2005), existem três paradigmas do processo evolutivo da imagem: o pré-fotográfico, que são as imagens produzidas artesanalmente; o fotográfico, que são as imagens produzidas na captação de fragmentos do mundo real; e o pós-fotográfico, que são as imagens sintéticas e infográficas, feitas por computador, que é o caso desta vinheta. As imagens em sua maioria no formato pictográfico constroem o diálogo, em conjunto com o discurso verbal realizado pelo locutor que lê a seguinte mensagem:

\footnotetext{
“Esse pode ser o seu intervalo, o meu ou o de todos nós. Você pode escolher mudar de canal, ou simplesmente continuar assistindo.

Esse é o país onde você, eu e tanta gente vive. Você pode escolher mudar um monte de coisas nele, ou simplesmente ficar assistindo.

Esse pode ser o lugar onde você, eu ou qualquer um de nós trabalha. Você pode ter escolhido esse lugar por paixão, por necessidade, ou pelos dois.

Essa pode ser a escola onde você estuda e estudou. Você pode não ter escolhido estar aqui. Mas, os seus pais escolheram a educação como um presente pra você. Você nasceu nessa casa. Você não escolheu a sua família ou o tipo de educação que recebeu, mas apesar disso você nasceu para fazer escolhas.

Num momento em que a dor é inevitável, que a esperança seja uma escolha." (CANAL FUTURA, 2011).
}

A imagem e o texto estão unidos, complementando-se, inclusive, em alguns momentos aparecem na imagem, palavras e frases do texto falado. Como vinheta o vídeo busca comunicar em pouco tempo, que normalmente é o do intervalo comercial comunicar a mensagem, que neste caso, foi veiculado no Canal Futura, que tem uma grande preocupação social, e utiliza do momento factual para levar esperança e paz por meio de sua mensagem híbrida, ligando imagem e linguagem verbal.

Percebe-se assim, que são utilizados vários ícones para construir o discurso do texto da imagem, em que por meio de pictogramas se remete ao objeto do signo, seja um ser humano, uma casa, uma escola, um local de trabalho, os pais, ou até sentimentos como a paixão e a necessidade financeira são representadas por meio de pictogramas, em tons pálidos, criando um clima fúnebre e de tristeza, como podemos ver nas figuras abaixo (Fig. 01 e 02). 

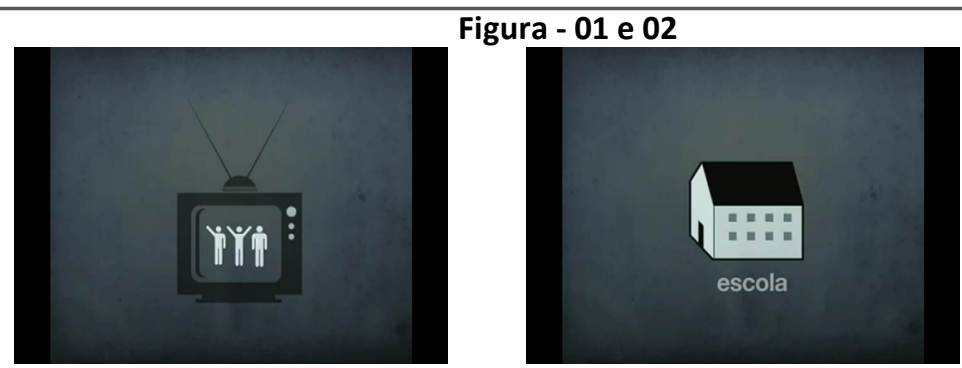

O objeto final do discurso é a esperança, promovida diante de um momento de dificuldade para todo o país, e em especial para as famílias das vítimas da chacina de Realengo. Percebe-se isso, ao final do vídeo em que se utiliza cores na tela, criando uma paisagem artificial com os pictogramas, com o verde, sinal de esperança predominando na tela, conforme a imagem abaixo (Fig. 03):

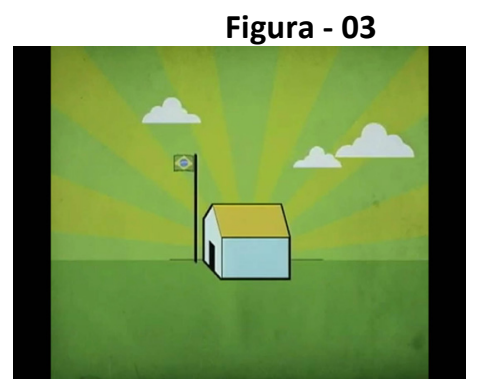

O efeito que os pictogramas e a mensagem verbal está apta a produzir nos espectadores do vídeo é o interpretante do signo vinheta. E esta funciona como mediador entre o que os produtores quiseram transmitir aos telespectadores. $O$ discurso verbal feito num tom intimista e pessoal, sem trilha de fundo acaba por gerar uma eficácia maior no interpretante dando um apelo maior à mensagem.

O vídeo fala sobre a esperança, usando como pano de fundo, a Chacina de Realengo, deixando claro, que mesmo que em algumas circunstâncias da vida o ser humano não tenha escolhas, ele sempre terá a opção de escolher o que fazer de sua vida, participar ativamente na mudança do mundo, em busca de um futuro melhor, ou ficar esperando que as coisas aconteçam, vivendo de forma indiferente, ou até hostil, querendo achar culpado para as coisas. $O$ vídeo tenta trazer a tona a responsabilidade que cada ser humano tem em construir um mundo melhor, mesmo diante de desastres, escolhas erradas e momentos de desespero. Sempre haverá a possibilidade de se escolher a esperança.

No referente qualitativo (quali-signo) podemos perceber que a vinheta é feita num quadro, com vários pictogramas passando em movimentos sutis ou estáticos, dando ênfase em cada objeto representado, sempre sob o mesmo ponto de vista, o de frente, não criando uma perspectiva de profundidade durante quase todo o vídeo, pois os objetos são expostos sob uma parede cinza e os pictogramas em tons neutros, sem muito contraste. As transições entre os objetos são realizadas em "fade" onde um desaparece para a entrada do outro, reforçando a serenidade e calma da vinheta, que segue a voz do locutor, num tom sério e seco, sem efeitos ou trilha sonora. No final, do vídeo a vinheta ganha um ar um pouco mais alegre, com tons de verde, e nuvens em movimento, numa simulação de natureza e profundidade, quando o locutor fala sobre a esperança, e o fechamento do VT continua com o tom verde, dessa vez com a logo do canal, em movimentos circulares.

$\mathrm{Na}$ análise do modo existencial (sin-signo) percebe-se que a produção foi feita para veicular em rede nacional pelo Canal Futura, e tem um tempo de 75", com o objetivo de trazer esperança para aqueles que assistirem de que não é uma tragédia que vai acabar com as esperanças ou fazer com que todo o mundo seja algo ruim. Mas, ao contrário, conscientiza, de que cada um é responsável pelas suas próprias escolhas, e que isso pode sim, mudar o futuro e tornar o mundo melhor ou pior. Cada quadro é a expressão de algo único para o momento, mesmo que os pictogramas sejam conhecidos por todos e bem genéricos, pois está presente nessa produção que é única. Então, desde a televisão, quando se fala daquele bloco comercial, em que se compara com todos os telespectadores, utilizando a imagem 
do pictograma de pessoas que será repetido por todo o VT, quando se referir aos seres humanos, até a casa do final, primeiramente com a bandeira a meio mastro e no final com a bandeira içada no alto, e com as cores na tela, são imagens particulares para quem assiste, naquele momento único, os objetos ali representados.

O vídeo feito por pictogramas e representações simbólicas é enredado com o texto, em voz off, com um homem fazendo a locução, em que ambos se complementam o tempo todo. Cada pictograma é por si só um legi-signo, pois eles são universais e já carregam em si, o significado que ele próprio representa. Ele tem um caráter emotivo, para poder tratar de forma correta sobre um assunto sensível, que era uma catástrofe sofrida por crianças, em uma escola, de modo covarde. A mudança de cor neutra, para colorido ao final, mostra que mesmo na tristeza, é possível acreditar num mundo melhor, e cheio de esperança.

Esse vídeo é predominantemente indicial, mas ainda assim possui aspectos icônicos presentes em sua produção, como os tons neutros e os coloridos, a voz dando o tom de seriedade e tristeza, além da frase final de impacto que fecha o VT, além da ausência de trilha sonora, como num momento de silêncio, que acontece pouco antes de acabar o vídeo, dos cinquenta e quatro segundos até um minuto e quatro segundos.

A realidade salta para fora da vinheta, visto que existe uma conexão com o tema de fundo e a mensagem passada pelo vídeo. Essa força indicial que existe no vídeo é pelo fato dele citar objetos que existem na realidade, representados pelos pictogramas que são de fácil associação com o mundo real.

No aspecto simbólico é válido ressaltar que o objetivo do vídeo é mostrar que a esperança é responsabilidade de cada ser humano, que tem o poder de escolha para mudar o mundo ou deixar que ele pereça. $O$ discurso que fala diretamente com o telespectador, o envolve e persuade a prestar atenção, junto com a sequência de símbolos conhecidos e de fácil interpretação.

O conteúdo do vídeo mostra em sua linguagem que ele é feito para que todos possam compreender não se pressupõe um repertório muito vasto, visto que os signos utilizados são bem conhecidos, e o contexto para quem viveu na época era implícito, e para quem não sabe, durante o tempo de exibição é explicado o que foi o acontecimento. $O$ vídeo é uma expressão do interpretante imediato, visto que sua compreensão é clara.

No nível do interpretante dinâmico verificamos que o que predomina, é o efeito emocional, visto que o vídeo causa uma comoção a quem assiste, certa tristeza pelo acontecimento, mas ao mesmo tempo um pensamento positivo de que se pode fazer um mundo melhor. Cria-se um despertar pelo cuidado com as crianças e jovens das escolas, amigos e companheiros de trabalho e de que está nas mãos de cada ser humano ajudar o outro a ser mais feliz. Assim, mesmo ele sendo emocional afeta um pouco no efeito da energia da ação e na conscientização do receptor.

Ao final chega-se a um bom entendimento da mensagem, pois a costura entre o texto e as imagens está bem feita, a representação feita pelos pictogramas são de fácil compreensão. É uma vinheta simples e objetiva que leva cada espectador a pensar em como cada um está agindo para que um mundo melhor aconteça.

\section{Conclusão}

Após a conceituação de assuntos relacionados a construção de sentido, a produção videográfica e os formatos midiáticos, pode-se perceber vários elementos do design utilizados no trabalho, e o sentido construído por eles a partir dos signos e suas representações, que a análise semiótica e seus diversos níveis pôde realizar.

\section{Referências}

CANAL FUTURA. Postado em 2006. Disponível em: <http://www.futura.org.br/main.asp? Team $=\{F A F 05500-95 D 5-4 F 67-866 F-60 D 4086978 D 7\}>$ Acesso em: 19 set. 2011. 
Ro> Acesso em: 13 jun. 2011.

FLUSSER, Vilém. O mundo codificado. São Paulo: Cosac Naify, 2007.

FRUTIGER, Adrian. Sinais e símbolos. São Paulo: Martins Fontes,1999.

LUPTON, Ellen; PHILLIPS, Jennifer C. Novos fundamentos do design. 1.ed. São Paulo: Cosac Naify, 2008.

MACHADO, Arlindo. Televisão levada a sério. São Paulo: Senac, 2000.

SANTAELLA, Lúcia. Cultura das Mídias. São Paulo: Experimento, 1996.

SANTAELLA, Lúcia. O que é semiótica? São Paulo: Brasiliense, 2002.

SANTAELLA, Lúcia. Semiótica aplicada. São Paulo: Thomson, 2005. 